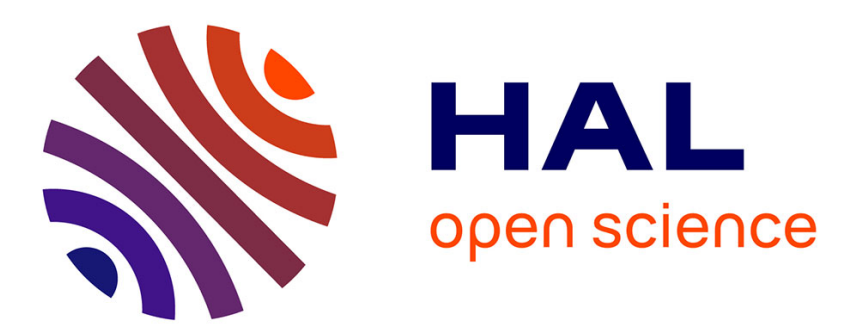

\title{
Chance between holism and reductionism: Tensions in the conceptualisation of Life
}

\author{
Charles T. Wolfe
}

\section{To cite this version:}

Charles T. Wolfe. Chance between holism and reductionism: Tensions in the conceptualisation of Life. Progress in Biophysics and Molecular Biology, 2012, Chance at the heart of the cell, 110 (1), pp.113-120. 10.1016/j.pbiomolbio.2012.05.005 . hal-01233183

\section{HAL Id: hal-01233183 \\ https://hal.science/hal-01233183}

Submitted on 24 Nov 2015

HAL is a multi-disciplinary open access archive for the deposit and dissemination of scientific research documents, whether they are published or not. The documents may come from teaching and research institutions in France or abroad, or from public or private research centers.
L'archive ouverte pluridisciplinaire HAL, est destinée au dépôt et à la diffusion de documents scientifiques de niveau recherche, publiés ou non, émanant des établissements d'enseignement et de recherche français ou étrangers, des laboratoires publics ou privés. 


\title{
Chance between holism and reductionism: tensions in the conceptualisation of Life
}

\author{
Charles T. Wolfe \\ Centre for History of Science, \\ Department of Philosophy and Moral Sciences, \\ University of Ghent \\ Blandijnberg 2, B-9000 Ghent \\ T +329264 3952, F +3292644187 \\ charles.wolfe@ugent.be
}

\begin{abstract}
In debates between holism and reductionism in biology, from the early twentieth century to more recent re-enactments involving genetic reductionism, developmental systems theory, or systems biology, the role of chance - the presence of theories invoking chance as a strong explanatory principle - is hardly ever acknowledged. Conversely, Darwinian models of chance and selection (Dennett 1995, Kupiec 1996, Kupiec 2009) sit awkwardly with reductionist and holistic concepts, which they alternately challenge or approve of. I suggest that the juxtaposition of chance and the holism-reductionism pair (at multiple levels, ontological and methodological, pertaining to the vision of scientific practice as well as to the foundations of a vision of Nature, implicit or explicit) allows the theorist to shed some new light on these perennial tensions in the conceptualisation of Life.
\end{abstract}

\section{Keywords}

Chance, reductionism, holism, organicism, Jean-Jacques Kupiec

Interest shifts . . f from an intelligence that shaped things once for all to the particular intelligences which things are even now shaping (Dewey 1910/2007, 10)

\section{Introduction}

The juxtaposition of chance with the more familiar pair of holism and reductionism in biology may at first sight seem rather surprising. Chance is both an ancient philosophical 
problem, as addressed - quite differently - by Aristotle, Lucretius or Diderot (Gigandet 2002, Wolfe 2010c, Pépin, this issue); a concept closely linked to the emergence of 'modern' biology, from Darwin to the study of genetic mutations; today it is discussed in a new way on both the experimental and theoretical planes, particularly in the more manipulable form of stochasticity: Kupiec et al. 2009, Kupiec 2010). Holism is a term that always carries with it a residual dimension of mystery, referring initially to a set of positions that goes back to Aristotle and Hegel, then - most relevantly for our topic here - to a position in theoretical biology inspired by general systems theory (Smuts 1926/1999, Ash 1995); in a more existential sense, it is also associated with the 'organicism' of Kurt Goldstein (Goldstein 1934/1995). Holism has also been revived more recently in analytic philosophy with Robert Brandom and John McDowell (for recent analyses of holism in metaphysics, philosophy of mind and the philosophy of language see Esfeld 1999 and Block 1998). But for our purposes 'holism' is a certain type of claim about how specifically living beings - organisms overall, but particularly live ones - should be considered as wholes, even if there is no rigorous, clear-cut distinction or relation between holism, systems theory and specifically organismic claims about the uniqueness of living beings. ${ }^{1}$

Briefly put, models appealing to chance are (philosophically) anti-essentialist: they reject the appeal to higher-level, irreducible properties of a system by retracing the causal process which generated them, based on stochastic processes. It seems intuitively right - and empirically indeed to be the case - that models favouring the role of chance tend to be compatible with reduction, or reductionism as an ontological and/or explanatory position according to which for any given Whole there will always be subjacent components which themselves can explain, with or without 'bonuses' such as bridge laws or structural features, the overall function of this Whole. But little attention has been paid to this relation between chance, anti-essentialism and reduction.

For instance, a Darwinian model of chance and selection (Dennett 1995, Kupiec 1996) seems to be in conflict with a systemic holism as put forth in Varela and his partisans

\footnotetext{
${ }^{1}$ The 'classic' authors Smuts, von Neumann and von Bertalanffy all waver in between statements of holism as a total systemic standpoint (with no particular reference to a special status for living entities) and holism as an approach or model which sheds particular light on embryology and how organisms are not mere machines (with reference to teleology and the 'historical' or 'learned' character of organisms). These authors also specify abstract terms on which 'merely mechanical aggregates' are different from genuine wholes, including chemical compounds, and then suddenly specify that biological organisms are the exemplars of "creative wholes," as Smuts calls them (wholes which create structures different from their constituents or parts) (Smuts 1926/1999, 140-141). The best general discussion of holism in early twentieth-century science is Ash 1995. See also Peterson 2010, which is forthcoming in book form from Springer (Series in History, Philosophy and Theory of the Life Sciences).
} 
(Weber and Varela 2002, Rudrauf et al. 2003), who tend to insist on the irreducible individuality of systems (or worse, a metaphysics of Life) rather than their production through stochastic processes, or similarly in their insistence on the existence of a foundational centre or Self in living systems (Wolfe 2010b). In contrast, this postulate seems absent from the work of Moreno and his collaborators (Ruiz-Mirazo et al. 2000), which shows that it is possible to articulate an organisational - and hence weakly holistic - model without adjoining it to the individualism or anti-Darwinism of a Varela (Bechtel 2007). I suggest that the juxtaposition of chance with the holism-reductionism pair (at multiple levels, ontological and methodological, pertaining to the vision of scientific practice as well as to the foundations of a vision of Nature, implicit or explicit) allows the theorist to shed some new light on these perennial tensions in the conceptualisation of Life.

1.

When we think of the role of chance in biology - the presence of chance, or more restrictively, 'stochastic processes' as productive in biology (and I leave aside the question, 'productive of what?' - of order? of particular organisms? of structures enabling the generation of organisms? - in order to merely stress: the idea that a chance and selection model is productive) we often think of Darwin. We can augment his ideas of variation and natural selection (in which chance plays the role of producing what sort of variation will occur in organisms living in a given environment, on which natural selection will then act) with later developments such as random mutations, genetic drift - the idea that most genetic variation we observe at the molecular level is not to be accounted for in terms of selection, but rather as a consequence of mutation and (random) genetic drift, in which the fixation of genes in populations is a purely stochastic process (Kimura 1983), etc. At that point one will typically enter into a 'more or less' discussion: is a particular factor decisive or not? Are its effects real or apparent? How many of these effects make a cause the cause of a phenomenon? But if we consider instead the attitudes towards the concept of chance within a schematic summary of the history of philosophy, in addition to debates about whether the world is the product of necessity or chance (with a predominant denial that chance can serve as any sort of explanatory factor, paradigmatically in Aristotle ${ }^{2}$ ), we find a different feature:

\footnotetext{
${ }^{2}$ To give just one example, when Aristotle discusses how it is that organisms come to be as organized, stable wholes, he clearly states, "organic development is either for the sake of something [i.e. according to a final
} 
a distinctly radical dimension of chance. The latter attitude is radical in the sense that it is destructive or at least deflationary: it says, 'show me a complex phenomenon A and I will show you how chance / variation-and-selection / stochastic processes B have produced it'.

Thinkers such as Lucretius, Diderot, more recently Daniel Dennett and - centrally to this essay - Jean-Jacques Kupiec have actively insisted on the role of chance or a fundamental randomness at the heart of nature, as either 'productive of order' or in any case a more basic, 'genuine' level of reality than the perceived forms and species of our experience. Conversely, numerous other thinkers of some eminence (Aristotle and Kant come to mind) have warned against the dangers of a theory which grants such a productive and fundamental role to chance, in the name of the stability or integrity of Forms, of the organism (as in Hans Jonas, e.g. Jonas 1966, 74-92), or of the person: if, so these thinkers argue, we open the door to explanations by chance, then none of the entities we depend on for a meaningful life can remain. In all cases here, what is at issue is chance as a feature of the world, not as a feature of our knowledge conditions (as in unpredictability or novelty understood as epistemological categories). What happens if we try and confront these aspects of the history of philosophy, with some key moments in theoretical biology? The confrontation reveals a certain instability or, differently put, a degree of conceptual incommensurability. That is, the introduction of chance renders the traditional opposition between holism and reductionism more unstable - less clear-cut.

We are familiar with various forms of this opposition, particularly, as regards the present context, that between holism as the insistence on the irreducible organizational dimension of systems (whether in the sense of autopoiesis, the more recent Developmental Systems Theory or DST, as in Oyama 1985/2000, or the role of development which 'trumps' reductive genetic explanations), and reductionism as a series of factually rather distinct possible claims: that 'you are your biochemistry' (Loeb 1912), that one should focus on reduction towards the molecular level (molecular biology or cellular neuroscience rather than cognitive neuroscience, Bickle 2006), or towards the genetic level (Monod, Dawkins, Dennett, etc.). But it should be clear that in fact they are not logical opposites; the opposition is less monolithic than it seems. Even a classic of genetic reductionism like Monod can move within one sentence from proclaiming genetic reductionism, "Thus defined, the theory of the 
genetic code is the fundamental basis of biology" to a much more flexible position, with anti-determinist or at least non-determinist tones: "this does not mean, of course, that the complex structures and functions of organisms can be deduced from [the theory of the genetic code], nor even that they are always directly analysable on the molecular level" (Monod 1970, 12; Monod 1971, xii). Again, there is no real contradiction here, especially if we consider that there is a difference between the claim of genetic determinism and that of genetic reductionism: the latter is a more flexible claim. As Gayon suggests, genetic reductionism "does not claim that genes wholly determine the genesis of organismic traits, but that the explanation of these traits must significantly include genetic factors." On this view, "the best explanation of a biological trait is that which specifies the way in which genes determine this trait in a given organismic and environmental context" (Gayon 2009/2011, 81/117). Reduction here is neither a strict ontological claim about what is real and what should be eliminated from our vision of Nature, nor a strict nomological claim about inter-theoretic reduction between sets of laws. It is, Gayon suggests, more of a heuristic claim about how to account for a biological phenomenon.

Conversely, organisational models are not adverse to defining the systems that compose the organisational wholes in which they are interested, in a mechanistic fashion (whether or not this is overtly reductionist; Bickle 2006, 430; Bechtel 2007, 270). That is, organisational models essentially articulate together key insights from mechanistic science and the holistic or 'organismic' critiques of mechanism. More precisely, they combine the mechanistic explanatory programme to study (by reduction, modeling and componential analysis) the structures at work in organisms, and the organicist (holist) standpoint which minimally "remind[s] mechanists of the shortfalls of the mechanistic accounts on offer," for ideas such as "negative feedback, self-organising positive feedback, and cyclic organisation are critical to explaining the phenomena exhibited by living organisms" (Bechtel 2007, 296297). Differently put, "system thinking does not imply forgetting about the material mechanisms that are crucial to trigger off a biological type of phenomenon/behavior; rather, it means putting the emphasis on the interactive processes that make it up, that is, on the dynamic organization in which biomolecules (or, rather, their precursors) actually get integrated" (Ruiz-Mirazo and Moreno 2004, 238).

But what of chance? It enables us to move away from the constant back-and-forth between reductionist models and more holistic models (strict genetic inheritance versus 
ecological inheritance, selfish genes versus organisms, genomics versus Evo-Devo and so on), in a kind of 'triangulation'. What Kupiec called 'cellular Darwinism' and now more expansively is calling 'ontophylogenesis' (a term somewhat reminiscent of Buss 1987, who also felt that evolutionary accounts of phylogenesis needed to be supplemented with accounts of ontogenesis, the emergence of individuals; Kupiec's idea is to be more Darwinian than Darwin, and explain, not just the origin of species but the origin of individuals through variation and selection; see summary in Laplane 2011) is as different from classic genetic reductionism as it is from the classic anti-reductionist positions which he suspects are too holistic (using the term in a more pejorative sense to mean views which are insufficiently grounded in experimental science). Indeed, instead of treating them as binary opposites, Kupiec finds these positions to be complementary types of mistakes:

Since genetic determinism is reductionist, holism would at first sight seem to be incompatible with it. Nevertheless, the two concepts unite in affirming the objective reality of order. In both cases a first principle is involved which structures the world and directs processes. In genetic determinism, the principle of order from order comes into play through the stereospecificity of the molecules, while in holism, the creative principle, less well defined and with a variety of names, creates organised wholes (Kupiec 2009, 77).

I'll return in closing to the challenge presented here towards any strong notion of order, but for now wish to focus more on where this view fits in relation to these 'mistaken positions' it challenges.

\section{2.}

Curiously, if we map out these positions in theoretical biology, they bear a striking resemblance to the landscape in contemporary moral philosophy - specifically regarding freedom versus determinism. A brief comparison should make this obvious. In analytic philosophy, the basic positions in the debate over whether we are free agents or simple parts of a deterministic universe, are usually presented as follows (with each of these obviously coming in different forms, weak or strong, pure or hybrid, etc.):

A: libertarianism (not to be confused with the political or economic doctrines which bear this name). Morally, this is the view that we are absolutely free, that agents respond to reasons, not causes, and are self-governing (rather than influenced by their genes, their environment, or what they had for breakfast). The libertarian may or may not accept that Nature is governed by causal processes, but she asserts that our existence as moral agents has 
nothing to do with these forms of causality. Biologically, this corresponds to a view found in German Idealist philosophy of nature (e.g. Hegel's), but also in Hans Jonas, in Varela and other thinkers calling either for a return to Aristotelianism or to a Romantic conception of Nature. They believe that 'Life' is entirely separate from physical science. There may or may not be a possible science of life on this view, but if there is, it will not resemble the science of Monod and Jacob, but rather that of Driesch, the Baldwin effect and Margulis.

Sometimes, however, these take the form of a more sophisticated, less metaphysically laden view which is still a form of organicism, without necessarily being what Monod and Kupiec call 'animism': for instance, the distinguished theorist of developmental systems, Susan Oyama, speaks of "the organism as layered vital reality," and insists on "the organism as a locus of agency" (Oyama 1985/ 2000, 162; Oyama 2000, 95). ${ }^{3}$

B: determinism is the most straightforward case here, in morals as in biological thought. It is the idea, whether or not we take it in its specifically Laplacian form, that there is a kind of grid on which all things are located (or more metaphysically, a grid including all future possibilities), such that causal, or mechanical, or atomic concepts exhaustively account for the behaviour of all such entities. Morally, it is the absolute opposite of the idea of freedom in the sense that I am the originator of my actions; scientifically, it supports the idea that there are absolute correspondences, whether between genes and behaviour, or laws of physics, etc. In early modern thought, when Hobbes claims that everything is matter and motion, including the thoughts in my head, this is a 'necessitarian' (determinist) view. Biologically, the most pure statement of determinism is to say that the phenotype is the expression of the genotype.

C: compatibilism is the most complex and the most interesting position, both in moral thought, where it involves recognising a degree of determinism while also arguing that we have what Dennett called some 'elbow room' within a deterministic universe. Spinoza's idea that the more I come to be aware of the causal processes within me and without me, the freer I am, is a compatibilist idea. The idea that I am governed by my beliefs, desires and conditioning rather than strictly by laws of physics (a view held by Hume, Moritz Schlick

\footnotetext{
${ }^{3}$ Elementary fairness leads me to specify that Oyama herself explicitly states that her position weakens the postulate common to what she calls - in a partly metahistorical way - preformationism and epigenesis, namely, the postulate that matter cannot acquire a biological form without there being an external source of this form. But it seems more interesting to me to present the tensions between 'sophisticated', nuanced theorists than between caricatural, dogmatic ones.
} 
and A.J. Ayer amongst others) is a compatibilist idea. What is the analog to compatibilism in the biological sphere? Precisely, the anti-essentialist privileging of chance (Lucretius, Diderot, Darwin, Dewey, Kupiec), which recognises the existence of causality without defending causal fundamentalism (a pluralism of causes, then). Indeed, to the criticism which might say, if we simply replace traditional essences by another concept called 'chance', aren't we still being essentialists?, one can reply that in both Darwin and Kupiec, chance, variation and selection are all factors ${ }^{4}$ :

Each cell, although working for its own good, is subordinate to the whole. It does not enjoy total freedom as its freedom is limited in that the cell is constrained to differentiate in a way appropriate to the place it occupies in the society of cells (Kupiec 2009, 124)

And of course if we think back to Claude Bernard, who popularized the term 'determinism' in the first place (Gayon 2009/2011; Pépin 2012), the relation is actually stronger than one of analogy, for Bernard makes a literal usage of 'freedom' and 'determinism' as descriptions both of biological entities and of methodological rules for dealing with such entities (Bernard 1865/1927, Part II, chapter II). Like Jacques Loeb in the early twentieth century, Bernard seeks to give analytic, mechanistic accounts of living systems while at the same time doing justice to their integrative features. But with respect to anti-essentialism, the idea is that position $(\mathbf{C})$, which in moral philosophy would be compatibilism, here in biological theory amounts to the rejection both of genocentric essentialism, and of holistic, systemic essentialism.

\section{3.}

This anti-essentialism entails, or rather is expressed crucially in the fact that, notably unlike Schrödinger in What is Life? (to name a famous, and perhaps foundational example; Schrödinger 1944), Kupiec does not recognize the existence of something like a program; "Because of the stochastic nature of protein interaction and gene expression, [Kupiec] says, there can be no Aristotelian form or program to give order to life and ward off entropic chaos and death" (Werner 2009, 35). Overall, the argument founded on chance and selection is anti-essentialist per definitionem because the primacy of chance over structure is the exact opposite of the Aristotelian insistence on the primacy of form over matter (Kupiec 1999).

\footnotetext{
${ }^{4}$ However, Kupiec approvingly cites the neural Darwinism of Changeux, then Edelman, which precisely seems to make the mistake of re-essentialising Darwinism as an explanatory principle (Kupiec 2009, 106).
} 
Evolution is not an essentialist business, for species are populational constructs (and organisms are not essence either, Wolfe 2010b). On a more pragmatic level, we can say with Ereshefsky that "Positing biological essences does not illuminate biological practice, nor does it help us understand how science works" (Ereshefsky 2010, 684). But Kupiec's claim is stronger:

modern biology is still impregnated with pre-scientific essentialism, hindering its development. This essentialism presents the Form as the prime entity and one that it seems impossible to go beyond, and gives rise to the contradiction in genetic determinism. We shall see that this impasse originates in the belief we have in the reality of the species. We are blinded by what seems absolutely obvious, and this leads us to see the species as the insurmountable horizon of biological thought (Kupiec 2009, 177).

And this puts us on a metaphysical plane, which enables me to relate Kupiec's 'Darwinian' anti-essentialism to a more strictly philosophical cousin, Althusser's 'Lucretian' antiessentialism. If Lucretius believed that the world was made up of atoms and their random swerves (clinamen) - which introduces a dimension of chance into what was otherwise a fairly static view of atomism - the late Althusser, in his posthumously published writings, speaks of a "materialism of the encounter," where the latter term refers to the sudden 'encounter' between atoms originally described by Epicurus and Lucretius:

the encounter doesn't create any of the reality of the world, which is nothing but agglomerated atoms, but it grants reality to the atoms themselves, which without the deviation and encounter would be nothing but abstract elements, without any tangible existence. The atoms' very existence is dependent on the deviation and the encounter (Althusser 1994, 541-542). ${ }^{5}$

There are no essences here, no Platonic forms or first principles like Aristotle's noûs ('mind' or 'intellect') which is prior to all contingent natural forms: "since nothing which is accidental is prior to what is per se, it is clear that no accidental cause can be prior to a cause per se. Spontaneity and chance, therefore, are posterior to noûs and nature"; Aristotle 1984, II.6, 198a7-10); there are encounters and their effects.

But the specifically biological anti-essentialism also makes a different point: that information itself is a kind of essence. Here the criticism is quite similar to that of, e.g. Susan Oyama, who writes that "when atheistic evolutionists deify information they seem to lack the courage of their materialist convictions" (Oyama 2009, 43). But if we recall my distinction between the three basic positions A, B and C, Oyama's critique of the informational model

\footnotetext{
${ }^{5}$ For English translations see Althusser 2006, and for extensive commentary see Bourdin 2005.
} 
of the gene belonged to (A), which opposed the intrinsic features of living beings to the 'disembodied' character of information (a criticism of a view as disembodied means the position argued for belongs to the family of theories defending 'embodiment', as discussed e.g. in Shapiro 2007). In contrast, 'cellular Darwinism' makes no claims about the uniqueness of organisms faced with the rest of the physical world.

Granted, not all the criticisms of 'disembodiment' belong to that shopworn category, 'mysterious vitalism' (while in any case vitalism exists and has existed in far more varied forms than biologists or philosophers of biology ever seem to notice; Oyama 2010, Wolfe 2011). That is, Oyama and others can state that the obsession with information theory dating back to Schrödinger leads people to lose sight of key features of, say, development, without this statement at all invoking mysterious, extra-causal forces like entelechies - although a prominent theorist of embodiment and former collaborator of Varela's, Evan Thompson, does reintroduce the metaphysical crispation that one might have hoped to have dispensed with, when he argues that "Life is not physical in the standard materialist sense of purely external structure and function. Life realizes a kind of interiority, the interiority of selfhood and sense-making" (Thompson 2007, 238). But Kupiec's criticism is different. When he criticizes genetics for its vision of ontogenesis as a unidirectional process leading from DNA to the phenotype (the expression of genetic information), he does so in the name of Darwinism, in that sense challenging the integrity of the Modern Synthesis (Kupiec and Sonigo 2000, 88; Schaeffer 2007, 173).

Both Darwin and Claude Bernard are inspirations for this anti-essentialist attitude towards the status of biological entities, which are de-substantialized here (as discussed in the 'five arguments' which open Chapter 2 of Kupiec 2009), or processualized; Bernard often insisted that the novel properties he was describing (ultimately the milieu intérieur or what we have come to call homeostasis) were not the properties of a special kind of substance (which would have been vitalism, in his view) but rather were properties of certain kinds of relations (Bernard 1865/1927, 66). In contemporary biology and close to Kupiec, a key moment was Lewontin's work, in which the organism becomes a porte-manteau concept, a place-holder in between gene, population and ecosystem (which themselves are strictly processual concepts as well); there is no privileging of any particular unit of selection as more 'real' or 'irreducible' than any other, in a selection process which involves nothing other than phenotypic variation, differential phenotypic fitnesses (depending on 
environments), and the heritability of fitness (Lewontin 1970, 1); "just as there is no organism without an environment, so there is no environment without an organism" (Lewontin 1983/1985, 99).

Because after all if we maintain, on a substantialist view, that organisms are something special - norganisms, in Julian Huxley's ironic phrase describing Haldane's reaction to his own mechanist views ${ }^{6}$ - we are guilty, or may be guilty, of "spiritualising matter," to borrow an expression from the eighteenth-century materialist philosopher La Mettrie - this mistake being akin to what Kupiec calls 'animism'. In the first pages of his notorious work L'Homme-Machine, La Mettrie charged that Leibnizians "with their Monads, ... have spiritualised matter rather than materialising the soul" (La Mettrie 1748/1960, 149), the irony being that precisely some of these versions of the Leibnizian monads, turned into 'molecules' or 'seeds of matter', in fact became, notably in Maupertuis, early theories of genetic information (Wolfe 2010a). Animism, spiritualising matter, mysterious embodiment: all of these are more or less identified in Kupiec's deflationary, Darwinian perspective which, as I shall discuss in closing, puts him closer to the reductionist standpoint.

\section{4.}

I suggested earlier that my proposed triangulation between holism, reductionism and chance produces some curious effects. Indeed, from Lucretius to Diderot, Darwin, and Tyndall $^{7}$ and onto Dennett and Kupiec, the type of biological theory that asserts the primacy of chance is reductionist in the sense that it rejects the existence of all irreducible totalities (including notions of design and order), without however being identical with classic forms of reductionism - which are historically diverse: Cartesian mechanism, biochemically inspired 'vulgar materialism' in the nineteenth century (Vogt, Büchner) or the revival of atomism, as stated for instance by Emil Du Bois-Reymond:

Natural science - or, more definitely, knowledge of the physical world with the aid of and in the sense of theoretical natural science - means the reduction of all change, in

\footnotetext{
6 "Dr. Haldane called himself an organicist, which implied being anti-mechanist and yet not a mystic vitalist I never quite grasped what he really meant. At any rate it led to some passages at arms. As I was describing some experiment which demanded a mechanistic explanation, he burst out with 'But it's a norganism, my dear young fellow, a norganism'!" (Huxley 1971, 138).

${ }^{7}$ John Tyndall (1820-1893) was an ideologist of Darwinism who in 1874 gave a very influential lecture at the British Association for the Advancement of Science in Belfast - thereafter known as the 'Belfast Address' (Tyndall 1874) - arguing for science against religion, but also making specific points about evolutionary theory and its impact on our thinking, as a demystifying force against teleology and other ideas; very much what Dennett was to describe as a "universal acid" (Dennett 1995, 63f.).
} 
the physical world to movements of atoms produced independently of time by their central forces; or, in other words, natural science is the resolution of natural processes into the mechanics of atoms (Du Bois-Reymond 1874, 17)

- or of course the more recent genetic or molecular reductionism, crisply described by David Hull as follows: "both scientists and philosophers take ontological reduction for granted... Organisms are 'nothing but' atoms, and that is that" (Hull 1981, 282).

Why is the Darwinian-inspired form of reductionism different from the above cases? Because they all amount to so many “ontological commitments" in Quine's sense (an ontological commitment means a commitment towards the existence of a particular set of objects: one thinker may believe in the existence of tables, chair but also mathematical entities as real, while another might 'commit' to all three of these plus unicorns, so that their respective commitments correspond to a type of statement which is only true if objects of this type exist; Quine 1961, 8, 12). The other forms of reductionism all are committed to a traditional distinction between the essential and the contingent, permanence and change ... whereas theories founded on chance are by definition, anti-essentialist.

Recall the comparison I sketched out above, between Kupiec's Darwinian invocation of chance contra essences, and Althusser's Lucretian invocation of the "random encounters" of molecules. One might object that the first is a scientific claim, in contrast to the second which is a philosophical usage of an ancient text - which itself seamlessly combined physics and metaphysics. But it seems that for Kupiec, as for Quine whom he does not mention, "ontology is part of the body of science itself and cannot be separated from it" (Quine 1961, 45, note 20, quoting Meyerson 1908/1951). And in both cases, the Lucretian/Darwinian insistence on chance as explanatory has (philosophically) anti-essentialist consequences what Dennett called a "universal acid" or a "universal solvent," in the sense of a method that dissolves many of our naïve preconceptions about the world, the objects that inhabit it as well our place in it (Dennett 1995, 63f., 521). Of course, Dennett's way of putting it keeps us in the safe zone where science is a reliable provider of truths (or practical regularities) and common sense or 'folk psychology' is like a naughty child that occasionally has to be called back to order. In contrast, there is a different kind of radicalism implicit in the Lucretian project of "emptying the world of any substantiality, any necessity, any form that would be constitutive of its being -preventing any attempt to recreate a first philosophy" (Bourdin 2005, 142). Granted, Kupiec's target is not Plato or Descartes or Hegel, but rather a 
specifically biological essentialism. But, aside from the general Quinean point about the continuum on which both ontology and science are located, we can also specifically note that in dealing with the form/matter pair, the problem of 'information' and the dangers of the 'spiritualisation of matter', metaphysics is never far off.

The ontophylogenetic theory (Kupiec 2009), in which chance is primary, seems closer to reductionism than to holism, as described so far. But it certainly seeks to find a 'third way' between the two:

Ontophylogenesis allows us to escape from the fetters created by these two types of theory in which biological thought has been trapped throughout its history; and if it provides this new perspective, it is because it totally renounces specificity to make room for probability. It does not depend on any principle of order which may be inherent in matter or given a priori. The organism is produced in its context by a nonfinalist process in which environmental constraints act on intrinsically probabilistic molecular and cellular mechanisms. (Kupiec 2009, 203)

The concept of ontophylogenesis, as its name indicates, fuses ontogenesis (the production of the individual) and phylogenesis (the production of the species); for Kupiec, this means (i) that life relies on intrisically stochastic processes, (ii) that natural selection takes place in the internal environment, and (iii) that it is the causal agent for the formation of the organism. Leo Buss was perhaps the first to observe that "The Modem Synthesis has not generated a theory of ontogeny" (Buss 1987, 25), and he too stated, in the preface to his book, that he could not understand why one cannot be a holist and a reductionist at the same time (Buss 1987, vii, referring to John Tyler Bonner). However, Buss sees this as a kind of broadening of the Darwinian construct, different to Kupiec, whose radical, deflationary instincts steer him away from 'holistic Darwinism' and other odd constructs of the past twenty years of biological theory. Kupiec, despite his criticisms of genetic reductionism, is more 'reductionfriendly' than most of these thinkers seeking to expand the remit of Darwinism - be it through development, cultural evolution, niche selection or other means.

\section{5.}

One may ask at this point, what happens to the organism in this triangulation (where we seem to be moving in the direction of a kind of enhanced reductionism rather than holism)? At first, we get perhaps too strong a form of demystification (that is, reduction), with Kupiec's frequent accusations of 'animism' - that holism is animistic in the sense that it attributes an inherent creative force or activity to matter itself - which risk losing sight, not 
of the mysterious norganism or the organism as the bearer of an internal 'subjectivity' and 'temporality' which remove from it from the physical world, but at the very least, of the functional integration of organisms.

Consider the case of teleology. Kupiec wheels out the old, reliable war machine of the Scientific Revolution with its heroic demystification of the world (as bearer of, e.g. occult qualities) and rejection of final causes, along with animism (Kupiec 2009, 69). And it may be useful to dispel any residual concepts of a 'finalistic' teleology, which is often anthropomorphic, like that defended by the organismic biologist E.S. Russell:

The organism strives to persist in its own being, and to reach its normal completion or actualization, This striving is not as a rule a conscious one, nor is there often any foresight of the end, but it exists all the same, as the very core of the organism's being" (Russell 1950, 108, citing his own earlier work The Directedness of Organic Activities).

But it is simple enough to defend a weaker form of teleology, in which - in a classic sort of example - the moth's stripes or the polar bear's colour can be teleologically described - in a weak teleological sense - as pointing to the camouflaging as leading to the (past) natural selection of their colour; not to a strong teleological claim that this camouflage predicts something about the future. And it seems dogmatic to reject the existence of a weaker sense of an inherent teleology in organisms, including their functional integration (Ruse 1989, 1066). Surely Kupiec, as a Darwinian, could have allowed for at least as much as teleology in the biological world as Darwin did, not least given that if there is any teleology in Darwin's world, "it is only because there is also a great deal of chance and accident in it" (Depew and Weber 1996, 147). The argument against 'animism' is also too strong in the sense that it cannot do justice to the difference between organisational models (in the sense of Moreno et al.) as distinct from the more vitalistic, subjectivist models of organism like Varela's, which, like Goldstein, privilege interiority over a 'mere spatiality' (patently obvious in Weber and Varela 2002, and Rudrauf et al. 2003), calling for "an expanded notion of the physical to account for the organism or living being" (Thompson 2007, 238). Organisational models, like Kupiec's own ontophylogenesis, are not in the business of foundationalist ontological commitments.

However, on the other hand we also get an interesting kind of residual vitalism (in the non-pejorative sense in which this term also applies to Claude Bernard, who after all is 
something of a father figure in the analysis of ontophylogenesis). For Bernard knew how to play a double game, both reductionist and vitalist, depending on the level of analysis (Kupiec 2009, sections 6.1, 6.2; Coleman 1985, on Bernard). Bernard could almost be a selfish-gene theorist when he says that "organs and systems do not exist for themselves, but for the cells, for the innumerable anatomical elements which comprise the organic edifice" (Bernard 1879/1885, I, 358). The equivalent in Kupiec would be this anti-organicist statement: "there is no final aim in the organisation established of creating the organism for its own sake as an individual unit. It is the consequence of a process which ensures as best it can the life of cells" (Kupiec 2009, 124). But Bernard also has more vitalistic moments:

[W] hat distinguishes a living machine is not the nature of its physico-chemical properties, complex as they may be, but rather the creation of the machine which develops under our eyes in conditions proper to itself and according to a definite idea which expresses the living being's nature and the very essence of life (Bernard 1865/1927, 93).

The more Darwinian emphasis in Kupiec, like in Lewontin (or Dennett, or Dewey in their respective contexts) means that the question of 'what is an organism?' (or a "living machine" in Bernard's terms) is non-operative. Neither the questions posed by the theory nor the types of answer it seeks for, involve definitions of what an organism is; there is no particular insistence, e.g., on the idea that organisms are integrated entities rather than collections of discrete objects (Gould and Lewontin 1979, 585). We are closer here to the processual character of Lewontin's interactionism, as described above - where the organism is simply a place-holder for an intermediate location between various levels of a given system, including genes and environment. A more vitalist thinker would object here that by leaving ontology so far behind, we end up in a "night in which all cows are black" (Hegel 1807/1979, 9), like functionalism in the philosophy of mind, in which, as memorably expressed by its great defender Hilary Putnam, "we could be made of Swiss cheese and it wouldn't matter" (Putnam 1975, 291; for some critical assessment of functionalism see Wolfe 2006). That is, we end with a biophysics, a computational model, a mathematical model rather than with an embodied analysis.

\section{Conclusion}

The confrontation between chance, holism and reductionism - their triangulation, as I have called it, namely, the attempt to evaluate Kupiec's new brand of Darwinism in terms of 
its way of positioning itself with respect to these 'families' of theoretical positions produces a de-essentialised vision of Nature in general and the status of living beings in particular, without however entirely overcoming the need to address the latter status. Most interesting perhaps is what happens to the concept of determinism. For in the end, even if I initially noted the parallel between libertarianism, determinism and compatibilism on the one hand and their biological analogues (say, autopoiesis/organicism, genetic determinism and work such as Lewontin's and Kupiec's), what is really happening is a more subtle, more embodied reconstruction of certain components of determinism.

Determinism is less strictly opposed to stochasticity than one often hears. As Levins and Lewontin note, "the entire development of molecular biology shows the continuing power of simple deterministic models of the 'bête-machine' nor is there the slightest reason to introduce stochasticity into models of, say, how an increase in adrenalin secretion will affect the concentration of sugar in the blood" (Levins and Lewontin 1980, 70); "thus stochastic processes may be the basis of deterministic process and deterministic the basis of stochastic. They do not exclude each other" (ibid., 72). But the sort of determinism at work in either Levins and Lewontin, or Kupiec is a far cry from Dawkins' claim that we are “gigantic lumbering robots" programmed by our genes (Dawkins 1976, 21; useful discussion in Godfrey-Smith 2001). Kupiec's reappropriation of Darwinism away from the Modern Synthesis leads him to reject the 'phenotype as expression of the genotype' conception, in a way which injects Lucretian elements into the Darwinian framework. Similarly, the concept of reduction is still at work here, but not in such an ontologically strict sense; more as a heuristic (Gayon 2009/2011). Like Buss, Kupiec clearly feels that "the theory of evolution has never proven a static construct" (Buss 1987, 196).

Conversely, chance is not just an 'empty word', a word "devoid of meaning" as classic determinists would have it (e.g. D’Holbach 1770/1990, II.v, $158^{8}$ ); it has more creativity attached and, perhaps, a kind of ontological reality (for discussion see Merlin 2009/2011). Kupiec often insists that 'cellular Darwinism' is meant to break away from the opposition between holism and reductionism, between top-down and bottom-up perspectives. But this applies also to the equally venerable opposition between chance and

\footnotetext{
${ }^{8}$ D'Holbach (or Diderot, who is known to have contributed a good deal to the book) adds in a note to this passage, that "the molecules of matter may be compared to loaded dice, since they always produce certain predetermined effects; as these molecules vary essentially, in themselves and in their combinations, they are loaded in infinitely various ways" (D'Holbach 1770/1990, 159, note 41).
} 
determinism, which in some cases is a false dichotomy (Wolfe 2010c). For what looks like order at one level of organisation may look like disorder at another level; "notions such as those of 'direction,' 'organization' or 'randomness' should be explicitly relativized to the unit in a hierarchy where they become relevant" (Falk and Sarkar 1992, 470). Granted, from the standpoint of biology this privileging of chance need not entail either a holistic or a reductionist outlook, and conversely, emphasis on complex variation and selection models, taking Darwinism into, e.g. systems dynamics can be found elsewhere (Bickhard and Campbell 2003); but I am speaking in conceptual terms - and as noted, sometimes Kupiec also seems to be making a contribution to natural philosophy, much as Monod or Mayr did before him, and, albeit differently, as Oyama also does today. ${ }^{9}$ But to be clear, I am not claiming that what we learn here is a 'new theory of chance'; rather, it is an anti-essentialist vision of organisms or living systems which navigates between various excesses (holism and reductionism), using an appeal to chance, stochasticity and generally Darwinian concepts as a background.

Lastly, what I've called the Lucretian elements in Kupiec's Darwinism also explain its deliberate demystifying tone, challenging our anthropomorphic conceptions - of what a species is (following Darwin) or even an individual, over which there is after all so little consensus. This challenging aspect matches up with what Dennett called the "universal acid" aspect of evolutionary theory, which, oddly enough, Hans Jonas had also noted, a generation earlier - and in his conceptual world this became "existentialism": "nineteenth-century evolutionism, which completed the Copernican revolution in ontology, is an apocryphal ancestor (along with the more official ones) of present-day existentialism" (Jonas 1966, 47). Indeed, Dennett too acknowledges that evolutionary theory can have the effect of making most of our intuitions about life seem absurd (Dennett 1995, 153). But whether we identify this type of thinking as Lucretian, Darwinian, or existentialist, we should clearly see its challenge to hyper-rationalist or architectonic conceptions of order: the anti-essentialist dimension implies a rejection or at least a cautionary attitude, towards both the faith in the absolute, autonomous existence of higher-level systems (as found often in organicist theory) and the faith in the absolute explanatory power of componential analysis (as found always in reductionism).

\footnotetext{
${ }^{9}$ I thank both reviewers for remarks leading me to see this point.
} 
Recall Kupiec's point that both reductionism (specifically, genetic determinism) and holism posit "a first principle ... which structures the world and directs processes," a “principle of order” (Kupiec 2009, 77). Contemplating Kupiec's work today, I am reminded of Goethe's rather pitiful confession of fear, faced with the Lucretian anarchy of Diderot's world - he doubtless would have felt the same about Darwin; and today about Kupiec. Reacting to the materialist Diderot (who he also admired, and whose novel Le Neveu de Rameau he translated into German), Goethe, thinker of morphogenesis, Urpflanze and a hierarchy in Nature, wrote: “Astonishing and excellent Diderot, why always use your great intellectual powers to produce disorder rather than order?" (Goethe 1798/1998; Goethe 1996, 196). This disorder is that of the living world in its unpredictability - teratological, transformist, classically-Darwinian or cellular-Darwinian.

\section{Acknowledgments}

I thank Thomas Pradeu for his critical remarks on an earlier draft, and I benefited greatly from the reviewers' comments.

\section{References}

Althusser, L., 1994. Écrits philosophiques et politiques, vol. 1, (Ed.) F. Matheron. Stock/IMEC, Paris.

Althusser, L., 2006. Philosophy of the Encounter: Later Writings, 1978-1987, F. Matheron, O. Corpet (Eds.), G.M. Goshgarian (Trans.). Verso, London.

Aristotle, 1984. Physics, in: Barnes, J. (Ed.), The Complete Works of Aristotle, vol. 1. Princeton University Press, Princeton.

Ash, M. G. 1995. Gestalt Psychology in German Culture. Cambridge University Press, Cambridge.

Bechtel, W., 2007. Biological mechanisms: Organized to maintain autonomy, in: Boogerd, F., Bruggeman, F.J., Hofmeyr, J-H.S., Westerhoff, H.V. (Eds.). Systems Biology:

Philosophical Foundations, Elsevier, Amsterdam, pp. 269-302

Bernard, C., 1865/1927. An Introduction to the Study of Experimental Medicine. Henry Schuman, New York. 
Bernard, C., 1879/1885. Leçons sur les phénomènes de la vie communs aux animaux et aux végétaux, vol. 1. J.-B. Baillière, Paris.

Bickhard, M.H., Campbell, D.T., 2003. Variations in variation and selection: the ubiquity of the variation-and-selective-retention ratchet in emergent organizational complexity. Foundations of Science 8: 215-282. DOI: 10.1023/A:1025046917589

Bickle, J., 2006. Reducing mind to molecular pathways: explicating the reductionism implicit in current cellular and molecular neuroscience. Synthese 151, 411-434. DOI : $10.1007 / \mathrm{s} 11229-006-9015-2$

Block, N., 1998. Holism: Mental and Semantic, in: Craig, E. (Ed.), Routledge Encyclopedia of Philosophy. Routledge, London, pp. 488-493.

Bourdin, J.-C., 2005. La rencontre du matérialisme et de l'aléatoire chez Louis Althusser. Multitudes 21:2, 139-147. DOI : 10.3917/mult.021.0139, URL http://www.cairn.info/revue-multitudes-2005-2-page-139.htm

Buss, L.W., 1987. The Evolution of Individuality. Princeton University Press, Princeton.

Coleman, W., 1985. The cognitive basis of the discipline: Claude Bernard on physiology. Isis 76, 49-70. DOI: 10.1086/353737

Dawkins, R., 1976. The Selfish Gene. Oxford University Press, Oxford.

Dennett, D.C., 1995. Darwin's Dangerous Idea. Simon \& Schuster, New York.

Depew D., Weber B., 1996. Darwinism Evolving: Systems Dynamics and the Genealogy of Natural Selection. MIT Press, Cambridge, Mass.

Dewey, J. 1910/2007. The Influence of Darwin on Philosophy, in: The Influence of Darwin on Philosophy and Other Essays, Hickman, L., Browning, D. (Eds.). Southern Illinois Press, Carbondale, IL, pp. 5-12

Du Bois-Reymond, E., 1874. The Limits of our Knowledge of Nature (original publication 1872), translated in Popular Science Monthly 5, 17-32

Ereshefsky, M., 2010. What's Wrong with the New Biological Essentialism. Phil. Sci. 77:5, 674-685. Stable URL: http://www.jstor.org/stable/10.1086/656545

Esfeld, M., 1999. Physicalism and Ontological Holism. Metaphilosophy 30:4, 319-337. DOI: http://dx.doi.org/10.1111/1467-9973.00141

Falk, R., Sarkar, S., 1992. Harmony from discord. Biol. Phil. 7:4, 463-472, DOI: 10.1007/BF00130064.

Gayon, J., 2009/2011. Déterminisme génétique, déterminisme bernardien, déterminisme laplacien, in : Gandrillon O., Kupiec J.J., Morange M. (Eds.), Le hasard au cour de la cellule, Syllepse, Paris, 79-90 ; new edition, Editions Matériologiques, Paris, pp. 115-129 
Gigandet, A., 2002. Lucrèce vu en songe. Diderot, Le rêve de D'Alembert et le De rerum natura. Rev. Mét. Mor. 35:3, 415-427. DOI: 10.3917/rmm.023.0415.

Godfrey-Smith, P., 2001. Three Kinds of Adaptationism, in: Orzack, S. H. \& Sober, E. (Eds.), Adaptationism and Optimality. Cambridge University Press, Cambridge, pp. 335 357.

Goethe, J.W., 1798/1998. Diderots Versuch über die Malerei, in: Goethe, Ästhetische Schriften, 1771-1805, (Ed.) F. Apel. Deutscher Klassiker Verlag, Frankfurt (Sämtliche Werke, Bd. 18), pp. 559-608.

Goethe, J.W., 1996. Écrits sur l'art, J.-M. Schaeffer (Trans.). GF-Flammarion, Paris.

Goldstein, K., 1995. The Organism: a Holistic Approach to Biology derived from Pathological Data in Man (original publication 1934). American Book Company, New York; reprint, Zone Books, New York.

Gould S., Lewontin R., 1979. The Spandrels of San Marco and the Panglossian Paradigm: a Critique of the Adaptationist Programme. Proc. Roy. Soc. Lond. B Biol. Sci. 205, 581-598. DOI: $10.1098 / \mathrm{rspb} .1979 .0086$

D’Holbach, Baron P.-H.T., 1990. Système de la Nature ou des lois du monde physique et du monde moral (original publication 1770), (Ed.) J. Boulad-Ayoub. Fayard-'Corpus', Paris.

Hegel, G.W.F., 1807/1979. Phenomenology of Spirit (Trans.) A.V. Miller. Oxford University Press, Oxford.

Hull, D., 1981. Philosophy and Biology, in: Fløistad, G. (Ed.), Contemporary Philosophy: A New Survey, vol. 2, Martinus Nijhoff, The Hague, pp. 281-316.

Huxley, J., 1971. Memories. Harper \& Row, New York.

Jonas, H., 1966. Is God a Mathematician? The Meaning of Metabolism, in: Jonas, The Phenomenon of Life. Towards a Philosophical Biology Harper \& Row / Dell, New York, pp. 64-98.

Kimura, M., 1983. The Neutral Theory of Molecular Evolution. Cambridge University Press, Cambridge.

Kupiec, J.-J., 1996. A Chance-Selection Model for Cell Differentiation. Cell Death Differ. 3, 385-390

Kupiec, J.-J., 1999. L'influence de la philosophie d'Aristote sur l'élaboration de la théorie de l'évolution et sur la génétique. Rev. Eur. Sci. Soc. 37:115, 89-116. Stable URL: http://www.jstor.org/stable/40370372

Kupiec, J.-J., 2009. The Origin of Individuals. World Scientific, Singapore. 
Kupiec, J.-J., 2010. On the Lack of Specificity of Proteins and its Consequences for a Theory of Biological Organization. Prog. Bioph. Mol. Bio. 102, 45-52.

DOI:10.1016/j.pbiomolbio.2009.11.002

Kupiec J.-J., Sonigo, P., 2000. Ni Dieu, ni gène. Éditions du Seuil, Paris.

Kupiec J.-J., Gandrillon, O., Morange, M., Silberstein, M., (Eds.) 2009/2011. Le hasard au cœur de la cellule. Probabilités, déterminisme, génétique. Syllepse, Paris; new expanded edition, Editions Matériologiques, Paris.

de La Mettrie, J.O., 1748/1960. L'Homme-Machine. ed. A. Vartanian. Princeton University Press, Princeton.

Laplane, L., 2011. Le mystère de la genèse des individus. Critique 764-765, 143-152

Levins, R., Lewontin, R.C., 1980. Dialectics and Reductionism in Ecology. Synthese 43:1, 47-78. DOI: $10.1007 /$ BF00413856

Lewontin, R.C., 1970. The Units of Selection. Ann. Rev. Ecol. Syst. 1, 1-18. DOI: 10.1146/annurev.es.01.110170.000245

Lewontin, R.C., 1983/1985. The Organism as the Subject and Object of Evolution. Reprinted in Levins, R., Lewontin, R.C., The Dialectical Biologist, Harvard University Press, Cambridge, Mass., pp. 85-106.

Loeb , J. 1912. The Mechanistic Conception of Life: Biological Essays. University of Chicago Press, Chicago.

Merlin, F. 2009/2011. Pour une interprétation objective des probabilités dans les modèles stochastiques de l'expression génétique, in: Gandrillon O., Kupiec J.-J., Morange M. (Eds.), Le hasard au cour de la cellule, Syllepse, Paris, pp. 79-90 ; new edition, Editions Matériologiques, Paris, pp. 215-252.

Meyerson, E., 1908/1951. Identité et réalité, Vrin, Paris.

Monod, J. 1970. Le Hasard et la nécessité. Essai sur la philosophie naturelle de la biologie moderne, Éditions du Seuil, Paris.

Monod, J., 1971. Chance and Necessity: An Essay on the Natural Philosophy of Modern Biology. Alfred A. Knopf, New York.

Mossio, M., Moreno, A., 2010. Organisational Closure in Biological Organisms. Hist. Phil. Life Sci. 32:2-3, 269-288

Oyama, S., 1985/2000. The Ontogeny of Information: Developmental Systems and Evolution. $2^{\text {nd }}$ revised edition, Duke University Press, Durham, NC.

Oyama, S., 2000. Evolution's Eye: A Systems View of the Biology-Culture Divide. Duke University Press, Durham, NC. 
Oyama, S., 2009. Compromising Positions: The Minding of Matter, in: Barberousse, A., Pradeu, T. et al. (Eds.), Mapping the future of biology. Evolving concepts and theories, Springer, Dordrecht, pp. 27-45.

Oyama, S., 2010. Biologists Behaving Badly: Vitalism and the Language of Language. Hist. Phil. Life Sci. 32:2-3, 401-423.

Pépin, F., 2012 . Claude Bernard et Laplace: d'un déterminisme physique vers un déterminisme proprement biologique ?, in: Charbonnat, P., Pépin, F., (Eds.), Matière première 2: Le déterminisme entre sciences et philosophie, 41-79. Paris : Éditions Matériologiques [materiologiques.com]

Pépin, F., n.d. The Randomness of Life. A Philosophical Approach Inspired from the Enlightenment. Prog. Bioph. Mol. Bio., this issue.

Peterson, E.L., 2010. Holism and Evolution in Biology and Anthropology: the Challenge of Gregory Bateson and C. H. Waddington to Biological Orthodoxy, 1924-1980. PhD

Dissertation, University of Notre Dame, Program in History and Philosophy of Science.

Putnam, H., 1975. Philosophy and our Mental Life, in: Putnam, Mind, Language, and Reality. Philosophical Papers, vol. 2. Cambridge University Press, Cambridge, pp. 291-303.

Quine, W.V.O., 1961. From a Logical Point of View, $2^{\text {nd }}$ ed., Harvard University Press, Cambridge, Mass.

Rudrauf, D., Lutz, A., Cosmelli, D., Lachaux, J.-P., Le Van Quyen, M. ,2003. From Autopoiesis to Neurophenomenology: Francisco Varela's Exploration of the Biophysics of Being. Biol. Res. 36:1, 27-65.

Ruiz-Mirazo, K., Etxeberria, A., Moreno A., Ibáñez J., 2000. Organisms and Their Place in Biology. Theor. Biosci. 119, 209-233. DOI: 10.1007/s12064-000-0017-1

Ruiz-Mirazo, K., \& Moreno, A., 2004. Basic Autonomy as a Fundamental Step in the Synthesis of Life. Artif. Life 10, 235-259. DOI:10.1162/1064546041255584

Ruse, M., 1989. Do Organisms Exist? Amer. Zool. 29, 1061-1066.

DOI:10.1093/icb/29.3.1061

Russell, E.S., 1950. The 'Drive' Element in Life. Brit. Jour. Phil. Sci. 1:2,108-116. Stable URL: http://www.jstor.org/stable/685806

Schaeffer, J.-M. , 2007. La fin de l'exception humaine. Gallimard- NRF, Paris.

Schrödinger, E., 1944. What is Life? The Physical Aspect of the Living Cell. Cambridge University Press, Cambridge.

Shapiro, L., 2007. The Embodied Cognition Research Programme. Philosophy Compass 2:2, 338-346. DOI: 10.1111/j.1747-9991.2007.00064

Smuts J.C., 1926/1999. Holism and Evolution. Sierra Sunrise Books, Sherman Oaks, CA 
Thompson, E., 2007. Mind in Life: Biology, Phenomenology, and the Sciences of Mind, Harvard University Press, Cambridge, Mass.

Tyndall, J., 1874. Address Delivered Before the British Association Assembled at Belfast, With Additions. Longmans, Green, and Co., London. Online at URL http://www.victorianweb.org/science/science texts/belfast.html

Weber, A., Varela, F.J., 2002. Life after Kant: Natural Purposes and the Autopoietic Foundations of Biological Individuality. Phen. Cog. Sci. 1, 97-125. DOI: 10.1023/A:1020368120174

Rudrauf, D., Lutz, A., Cosmelli, D., Lachaux, J.-P., Le Van Quyen, M. ,2003. From Autopoiesis to Neurophenomenology: Francisco Varela's Exploration of the Biophysics of Being. Biol. Res. 36:1, 27-65.

Werner, E., 2009. Evolutionary Embryos. Nature 460:2, 35-36. DOI:10.1038/460035a

Wolfe, C.T., 2006. Un matérialisme désincarné: la théorie de l'identité cerveau-esprit. Matière première 1, 77-100

Wolfe, C.T., 2010a. Endowed molecules and emergent organization: the Maupertuis-Diderot debate. Early Sci. Med. 15, 38-65. DOI:

http://dx.doi.org/10.1163/138374210X12589831573063

Wolfe, C.T., 2010b. Do Organisms Have an Ontological Status ? Hist. Phil. Life Sci. 32:2-3, 195-232

Wolfe, C.T., 2010c. Un colpo di dadi non cancelleràmai il caso: il determinismo lucreziano dopo Locke, in: Mormino, G., Morfino, V., del Lucchese, F. (Eds.), Lucrezio e la modernità . Bibliopolis, Naples, pp. 235-251.

Wolfe, C.T. 2011. Vitalism, in: Gargaud, M. et al. (Eds.), Encyclopedia of Astrobiology. Springer, Berlin, pp. 1749-1750. 